\title{
BIOLOGY AND POPULATION DYNAMICS OF BANANA SHRIMP (Penaeus merguiensis) IN THE TARAKAN WATERS, EAST BORNEO
}

\author{
Duranta Diandria Kembaren and Ali Suman \\ ${ }^{1}$ Research Institute for Marine Fisheries, Muara Baru-Jakarta \\ Received June 24-2013; Received in revised form December 05-2013; Accepted December 09-2013
}

\begin{abstract}
Study of biology and population dynamic of banana shrimp (Penaeus merguiensis) in Tarakan waters, East Borneo was carried out from January to November 2012. The aim of this research was to identify the biological aspects and population dynamics of banana shrimp. For estimating dynamic population, data were analysed using FiSAT II. The result showed that length at first capture (LC) of banana shrimp by mini trawl (pukat hela) was $35 \mathrm{~mm}$ and the size at first maturity (Lm) was 33,86 $\mathrm{mm}$ in carapace length. Spawning occured all year around and reached it's peak in March. The growth coefficient $(K)$ of banana shrimp was 1,45/year with carapace asymptotic length (CL") of 80 $\mathrm{mm}$. Total mortality rate $(Z)$ and natural mortality rate $(M)$ were 4,85/year and 1,76/year. While fishing mortality rate $(F)$ and exploitation rate $(E)$ were 3,09/year and 0,64, respectively. The exploitation rate of banana shrimp in Tarakan waters tended to be overexploited so that it needed to be managed wisely and carefully by reducing the fishing effort and fishing season especially on spawning season. The recruitment peak of banana shrimp occured in May.
\end{abstract}

\section{KEYWORDS : Biological aspect, population dynamic, banana shrimp, Tarakan waters}

\section{INTRODUCTION}

Having located at the northern of East Borneo waters, Tarakan waters is the concentration of potential shrimp fishing area. The development of shrimp as targets species in East Borneo was very rapid since 1975. Species group of banana shrimp (Penaeus merguiensis/ Fenneropenaeus merguensis), endeavour shrimps (Metapenaeus ensis and M.brevicornis) and tiger cat shrimps (Parapenaeopsis spp.) were the dominant species besides of tiger shrimp (Penaeus monodon) (Naamin, 1977; Research Institute for Marine Fisheries, 2012). Since trawl banned in 1988, mini trawl (pukat hela) was developed as the major shrimp fishing gear, followed by tidal traps such as splint and togo (Sumiono \& Djamali, 2006).

Production of penaeid shrimp in East Borneo during the last ten years was the higest with an average production of 16.726 tonnes per year and contribution to the total production was up to $17,16 \%$ per year (Center for Data Statistics and Information, 2012). Contribution of shrimp catch from Tarakan waters accounted for $9,2 \%$ of total shrimp production in East Borneo (Marine and Fisheries Service, 2011).

In Tarakan waters, shrimp fishing activity was conducted continuously over the year by using mini trawl (pukat hela) with body mess size of 1,5 inches and 1 inches in the code end (Research Institute for Marine Fisheries, 2012). This condition could lead to decline of shrimp resources. Stock assessment is Corresponding author:

Research Institute for Marine Fisheries, Muara Baru-Jakarta J. Muara Baru Ujung, Komp. PPS Nizam Zachman needed to implement a good management practice for sustainable shrimp resources. This study was conducted to determine the biological aspects and population parameters of banana shrimp in Tarakan waters.

Studies of penaeid shrimp population dynamics had been undertaken in many of Indonesian waters such as Arafura (Naamin, 1984), Cilacap (Suman, 1992; Suman \& Boer, 2005; Saputra, 2005; Saputra \& Subiyanto, 2007), Madura Strait (Setyohadi et al., 1999), Kotabaru (Suman \& Umar, 2010), and Bone (Kembaren et al., 2012). However, those assessment in Tarakan waters was rarely done.

\section{MATERIALS AND METHODS}

Sample of the shrimps species were collected from fishermen landed in Lingkas Ujung, Tarakan, East Borneo since January until November 2012 (Figure 1).

Biological parameters observation of the shrimp samples included of carapace length, sex, and maturity stage. Carapace length was determined using calliper with precision of $0,01 \mathrm{~mm}$, then it was tabulated into length-frequency table in class interval of $2 \mathrm{~mm}$.

Length at first capture (Lc) was estimated by plotting cumulative length frequency to acquire a standard logistic curve, then the intersection between curve and $50 \%$ of cumulative frequency was a length at first capture in a half of population (Saputra, 2005). 
Gonad maturity stage of banana shrimp was determined morphologically based on the criterion of shrimp gonad maturity index by Naamin, (1984) i.e. : quiescent/undeveloped (stage 1), developed (stage 2), early mature (stage 3 ), ripe (stage 4 ) and spent (stage 5). Gonad maturity divided into two categories, immature ( $1^{\text {st }}$ and $2^{\text {nd }}$ stage $)$ and mature ( $3^{\text {rd }}$ and $4^{\text {th }}$ stage).

Carapace length at first mature is estimated by using Spearman-Karber method (Udupa, 1986):

$$
m=X_{k}+\frac{x}{2}-\left(X \sum_{i=1}^{n} p i\right)
$$

where: $\mathrm{m}=\log$ size of shrimp at first mature;

Xk $=$ last log size at which $100 \%$ of shrimp are fully mature;

$X \quad=$ log size increment;

pi $\quad=$ proportion of fully mature shrimp in the $\mathrm{i}^{\text {th }}$ size group;

thus, the mean size at first maturity was given by antilog $(m)$.

From the length-frequency distribution of the samples, FiSAT II was used to obtain asymptotic carapace length (CL") and growth coefficient $(\mathrm{K})$ of von Bertalanffy Growth Function (VBGF). The best growth curve was then fitted on the basis of nonparametric scoring from the goodness of a fit index, called "Rn value" (Gayalino et al., 2005).

The length-converted catch curve method was used for estimating the instantaneous total mortality (Z) (Gayalino et al., 2005). For obtaining an independent estimate of the natural mortality (M), Pauly's equation, (1983) was applied :

$$
\begin{aligned}
\log (M)= & -0,0066-0,279 \log C L "+0,6543 \log K \\
& +0,4634 \log T \ldots \ldots \ldots \ldots \ldots \ldots \ldots \ldots \ldots .(2)
\end{aligned}
$$

The mean annual environmental temperature was taken as $29^{\circ} \mathrm{C}$ as the average of the monthly water temperature.

Fishing mortality (F) was calculated using following formula

$$
F=Z-M
$$

Exploitation rate $(E)$ obtained by dividing fishing mortality by total mortality (Pauly, 1983)

$$
E=\frac{\mathrm{F}}{\mathrm{z}}
$$

Recruitment pattern was estimated using the subprogram of FiSAT, where asymptotic carapace length (CL"), growth constant $(\mathrm{K})$, and age at zero size $\left(\mathrm{t}_{\circ}\right)$ were used as an input of parameters (Gayalino et al., 2005).

\section{RESULTS}

\section{Size at First Capture (LC) and First Maturity (Lm)}

The average size of banana shrimp at the first capture was determined without differentiating the sex. Based on the data analysis it was known that banana shrimp was captured by mini trawl (pukat hela) at the carapace lenght of $35 \mathrm{~mm}$. Standard logistic curve of the length at first capture is shown in the Figure 2.

Meanwhile, determining of the average size of banana shrimp at first maturity $(\mathrm{Lm})$ was only done for the female. The Spearman-Karber analysis showed that size at first maturity of banana shrimp was 33,86 $\mathrm{mm}$ in the range of $30,76-37,27 \mathrm{~mm}$ in carapace lenght. This value meant that the average size of captured banana shrimp was above the value of size at first maturity.

\section{Spawning seasons}

Spawning seasons could be identified through the observation of eggs distribution or through observation of gonad maturity stage of female shrimp in the waters as shown by Martosubroto, (1978). The monthly percentage of banana shrimp maturity in the Tarakan waters is shown in the Figure 3.

It was known that spawning occured almost all year around which was indicated by the presence of mature female shrimp in the month of observation. However, there was a trend that the percentage of mature shrimp was lower in the period of May to July and November. Meanwhile, the higher percentage of mature shrimp was on the period of March to April and September then reached its peak in March.

\section{Growth Rates}

Growth parameters of banana shrimp was analysed by using von Bertalanffy growth formula (Sparre \& Venema, 1999). Figure 4 is presenting the monthly banana shrimp carapace length frequency in the Tarakan waters. 


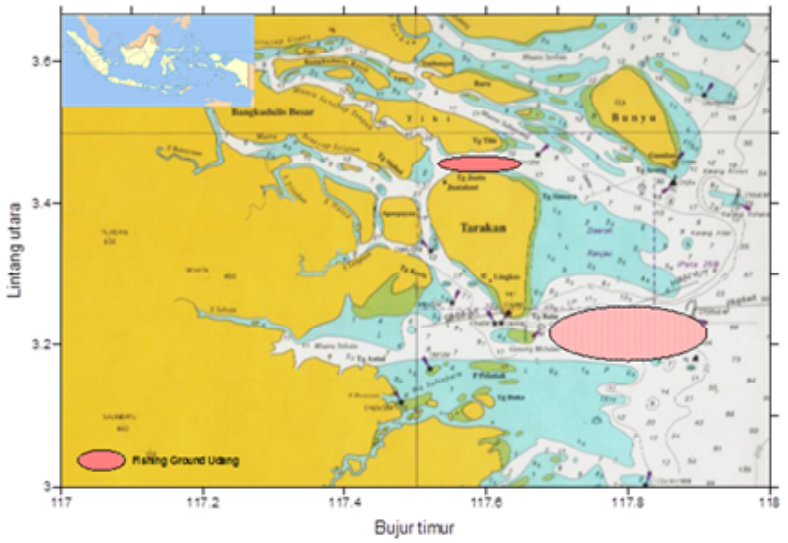

Figure 1. Fishing ground and sampling location.

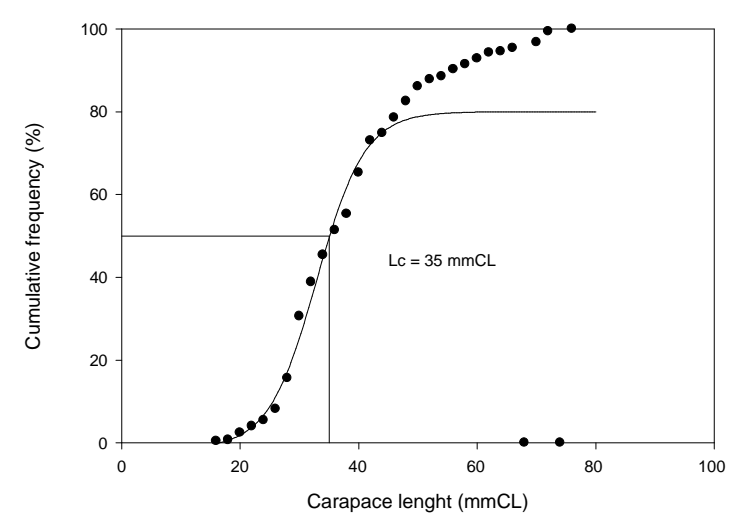

Figure 2. Average size of banana shrimp at first captured by minitrawl in Tarakan waters.

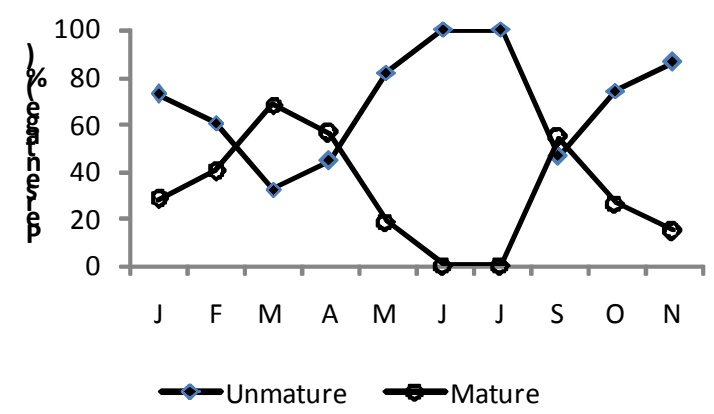

Figure 3. Monthly percentage of banana shrimp maturity in the Tarakan waters, 2012.

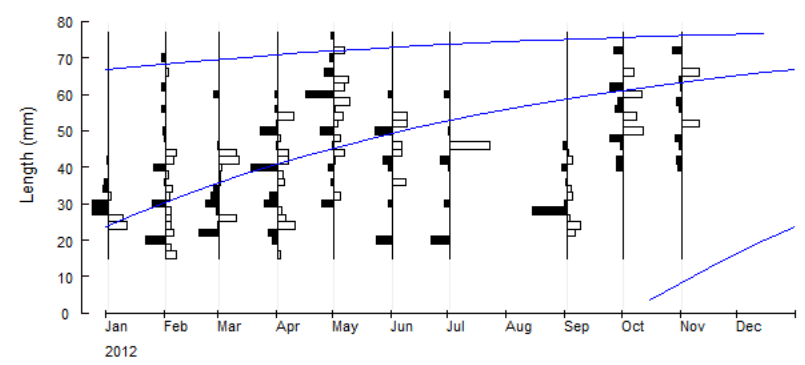

Figure 4. Distribution of banana shrimp carapace length frequency and growth formula in Tarakan waters, 2012.

According to this result, it is known that banana shrimp asymptotic carapace length (CL") is $80 \mathrm{~mm}$ and the growth rate $(\mathrm{K})$ is 1,45 per year.

\section{Mortality and Exploitation Rates}

Mortality rates was estimated by using the lengthconverted catch curve method that used growth parameters of banana shrimp i.e. asymptotic carapace lenght (CL") and growth rate (K) as input data (Figure 5).

\section{Length-Converted Catch Curve}

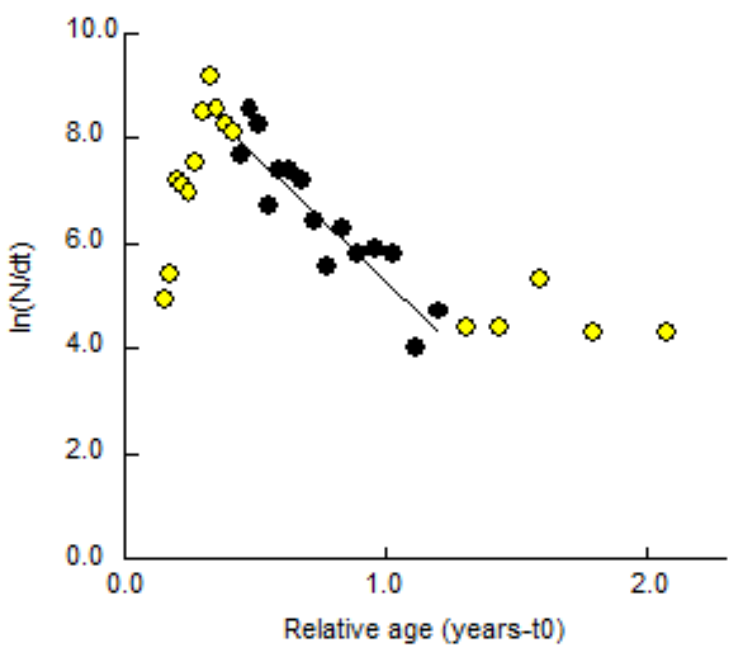

Figure 5. Length-converted catch curve of banana shrimp in Tarakan waters, 2012.

From this curve, it is informed that total mortality $(Z)$, natural mortality $(M)$ and fishing mortality $(F)$ are 4,85/year, 1,76/year, 3,09/year, respectively. Meanwhile, the exploitation rate (E) of banana shrimp is 0,64 .

\section{Recruitment Pattern}

Recruitment pattern of banana shrimp is presented in the Figure 6, it showed that there are two modes. The 
first mode occur on May with the percentage of reruitmen above $20 \%$ and the other occurs on August with the percentage of recruitment below $10 \%$.

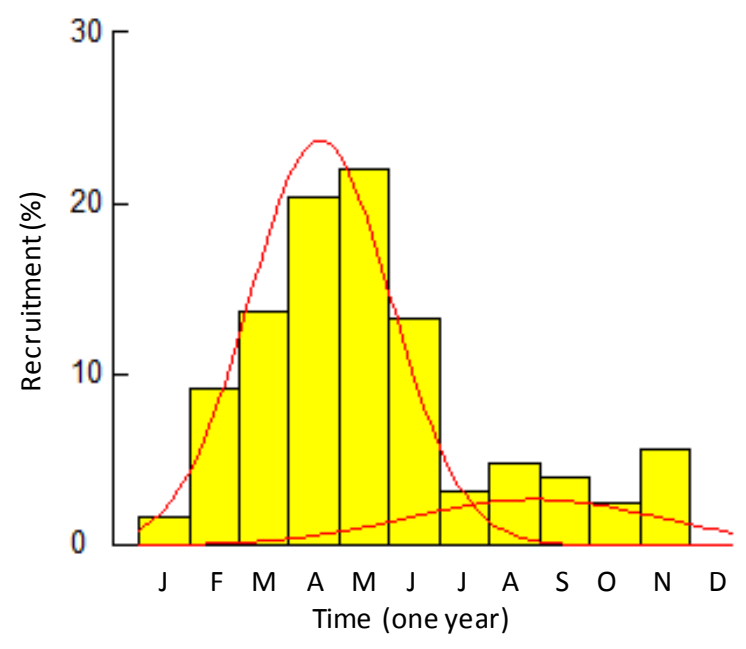

Figure 6. Recruitment pattern of banana shrimp in the Tarakan waters, 2012.

\section{DISCUSSION}

Lenght at first capture (Lc) of banana shrimp (Penaeus merguiensis) in Tarakan waters was higher than banana shrimp from others Indonesian waters i.e. Panimbang, northern West Java, Mayangan, Cilacap, and Bone waters where the Lc were 27,02 $\mathrm{mm}, 22,1 \mathrm{~mm}, 28,9 \mathrm{~mm}, 18 \mathrm{~mm}$, and $21,33 \mathrm{~mm}$, respectively (Suman \& Nugroho, 1988; Suman et al., 1991; Wedjatmiko \& Yulianti, 2003; Saputra \& Subiyanto, 2007; Kembaren et al., 2012). This phenomenon happened because of the different environmental condition and fishing gear used by fishermen. Indirectly, it also suggested that banana shrimp from Tarakan waters had bigger size than banana shrimp in others waters.

Lenght at first maturity $(\mathrm{Lm})$ had an important role in the fisheries management since fisheries resource utilization should let a certain numbers of shrimp brood stock in the same size or higher to achieve a maturity (Sudjastani, 1974). Therefore, size at first maturity was a population parameter that consider as indicator when the shrimp reached his maturity (Pinheiro \& Oliveira, 2006).

In the northern of Java waters, banana shrimp reached the first maturity size at the carapace length of $26-46,2 \mathrm{~mm}$ (Martosubroto, 1978; Suman \& Nugroho, 1988; Suman \& Subani, 1994; Wedjatmiko \& Yulianti, 2003), while in the southern Java was 31,64 $-39,9 \mathrm{~mm}$ (Adisusilo, 1983; Suman, 1996), in the
Bintuni Bay, Irian Jaya was $33,17 \mathrm{~mm}$ (Sumiono, 1983), and in the Nusa Tenggara Timur waters was 38,9-41,8 mm (Suman et al., 1991). In this study, banana shrimp reached their mature stage faster than that others waters. The different environment condition such as temperature, salinity, and food availability was the factors that influenced the different size of maturity. Udupa, (1986) found that size at maturity between species could be different even in the same species.

Spawning season could be estimated by comparing the frequency of percentage mature shrimp, where from this study the peak of spawning season occured in March. Other research shown that peak of spawning season occured in March to May and October to November (northern Java) (Naamin, 1971; Suman et al., 1991), April, August, and November (southern Java) (Adisusilo, 1983), and September (Kotabaru) (Suman \& Umar, 2010). These data illustrated that peak of spawning season in this study was as same as those in the northern Java and Kotabaru waters but rather different with the southern Java.

Asymptotic carapace length and growth rate of banana shrimp in Kotabaru waters were $44,3 \mathrm{~mm}$ and 1,4 per year (Suman \& Umar, 2010), in Cilacap waters were $37,5 \mathrm{~mm}$ dan 1,4 per year (Saputra \& Subiyanto, 2007), in Bone waters were $39 \mathrm{~mm}$ dan 1,2 per year (Kembaren et al., 2012). Asymptotic carapace length of banana shrimp in this study was higher than that of those waters.

Its growth rate $(\mathrm{K})$ tended to be higher than that others species, it is showed that growth rate of banana shrimp was high (Gulland, 1983; Naamin, 1984). High growth rate also indicated that shrimp has a short age and highly mortality rate species.

In Kotabaru waters, total mortality rate of banana shrimp was 4,52 per year, natural mortality rate was 1,96 per year, fishing mortality rate was 2,56 per year (Suman \& Umar, 2010), while in Cilacap waters, total mortality rate of banana shrimp was 7,02 per year, natural mortality rate was 1,96 per year, and fishing mortality was 5,06 per year (Saputra \& Subiyanto, 2007). The study of Kembaren et al. (2012) in Bone waters found that total mortality, natural mortality rate, and fishing mortality rate of banana shrimp were 7,86 per year, 1,90 per year, and 5,96 per year, respectively.

Fishing mortality rate of banana shrimp in this study had the same value with Kotabaru waters and lower than in the Cilacap and Bone waters. It seems that banana shrimp was fished intensively in this area. However, it was better than in the Cilacap and Bone 
waters, where juvenile of shrimp was exploited intensively.

The rational and sustainable value of exploitation rate should be lower than $0,5(E<0,5)$ or as high as $0,5(E=0,5)$, this condition would lead to the maximum sustainable yield (MSY). Exploitation rate of banana shrimp in the Kotabaru, Cilacap, and Bone waters were 0,$56 ; 0,72$; and 0,76 , respectively (Suman \& Umar, 2010; Saputra \& Subiyanto, 2007; Kembaren et al., 2012). Exploitation rate of banana shrimp in this waters was higher than that in Kotabaru waters and lower than that in Cilacap as well as that in Bone waters. Exploitation rate of banana shrimp in this study tended to lead to the overexploited. So that, the utilization of shrimp resources should be managed properly. Reducing fishing effort especially in March and September when the spawning season occoured is suggested in order to avoid recruitment overfishing.

Recruitment pattern has concerned to the spawning time (Ongkers, 2006). Although the result of FISAT program was rarely match with in the nature, however considering that this model was based on the two assumption that rarely occured in fact viz and all the samples was on one set of growth parameter and there was a month without the recruitment (Pauly, 1987; Gayalino et al., 2005). This model would still be useful to estimate how the shrimp/fish population recruitment take place in a year. Figure 6 shows that recruitment reached the peak in May. We assumed that it was related to the spawning season of banana shrimp in this waters where spawning peak occured in March. According to Dall et al., (1990), Penaeus shrimp attained sub-adult and entered the fishing area after 3-5 month old. Such was that case, it was estimated that the recruitment in May came from the spawning in March.

\section{CONCLUSION}

Length at first captured of banana shrimp with mini trawl (pukat hela) was $35 \mathrm{~mm}$ and size at first maturity was $33,86 \mathrm{~mm}$ in carapace lenght. The peak of spawning season occured in March and the recruitment peak in May. In this study, banana shrimp had the growth rate as same as the banana shrimp from the other waters. However, natural mortality rate was lower than that in other waters. Exploitation rate of banana shrimp tended to lead to the overexploited so that the utilization of the resources should be carefully and properly managed. It was suggested to reduce the fishing effort, especially in March and September.

\section{ACKNOWLEDGEMENT}

I would like to thank the head of the Research Institute for Marine Fisheries for his support on this activity, dealing on study of stock assessment and exploitation of penaeid shrimp and blue swimming crabs resources in the Fisheries Management Area 712 and 716 . This research was funded by APBN year of 2012.

\section{REFERENCES}

Adisusilo, S. 1983. Size on maturity and spawning season of banana shrimp (Penaeus merguiensis de Man) in Cilacap adjacent waters. Marine Fisheries Research Report 29: 97-102 (in Indonesian).

Center for Data Statistics and Information, MMAF. 2012. Marine and Fisheries Statistics 2011. Ministry of Marine Affairs and Fisheries. Jakarta. 136 p. (in Indonesian).

Dall, W, B.J. Hill, P.C. Rothlisberg, \& D.J. Staples. 1990. The Biology of the Penaeidae. In Advances in Marine Biology, Vol. 27, edited by J.H.S. Blexter and A.J. Southward. Academic Press, London. 489 p.

Marine Fisheries Service. 2011. Capture fisheries statistics of Tarakan. Tarakan Marine and Fisheries Service. Published anually. (in Indonesian).

Gayanilo, F. C. Jr., P. Sparre \& D. Pauly. 2005. FAOICLARM Stock Assessment Tools II (FiSAT II). Revised version. User's guide. FAO Computerized Information Series (Fisheries). No. 8, Revised version. FAO Rome. 168pp.

Gulland, J. A. 1983. Fish stock assesment. A Manual of Basic Methods. John Wiley \& Sons. Chicester. $233 \mathrm{pp}$.

Kembaren, D.D., B. Sumiono, \& Suprapto. 2012. Biology and growth parameters of banana shrimp (Penaeus merguiensis) in the Bone waters, South Sulawesi. In Suman, A, Wudianto, and B. Sumiono (Eds.). Status of fisheries resources in Makassar Strait, Bone Bay, Flores Seas, and Banda Seas. IPB Press. Bogor. 300 pp. (in Indonesian).

Martosubroto, P. 1978. Spawning season and growth of banana shrimp (Penaeus merguiensis de Man) and endeavour shrimp (Metapenaeus ensis de Haan) in Tanjung Krawang waters. Proceeding of 
the Second Seminar on Shrimp Fisheries. p. 720. (in Indonesian).

Naamin, N. 1971. Preliminary repport of shrimp spawning ground in the northern inshore of Central Java. Marine Fisheries Research Report 71: 18 (in Indonesian).

Naamin,N. 1977. Shrimp fisheries development in Indonesia. Proceeding of the Second Seminar on Shrimp Fisheries. Maret 1977. RIMF. Jakarta p: 55-65 (in Indonesia).

Naamin, N. 1984. Population dynamics of banana shrimp (Penaeus merguiensis de Mann) in the Arafura waters and its management alternatives. Dissertation. Post Graduate Faculty : Bogor Agricultural Institute. 277 pp. (in Indonesian).

Ongkers, OTS. 2006. Monitoring of red anchovies (Encrasicholina heteroloba) population parameters in the Ambon Bay In. Proceeding of the Fourth National Seminar on Fish in Jatiluhur $29^{\text {th }}-30^{\text {th }}$ August 2006. Cooperation of Indonesian Icthiology Society and Research Institute of Fish Stock Enhancement, RCCP-MMAF, Departmenet of Marine Fisheries Management IPB, and Biological Research Center LIPI: 31-40. (in Indonesian).

Pauly, D. 1983.Some Simple Methods for the Assessment of Tropical Fish Stocks. FAO Fisheries Technical Paper (254): 52 p.

Pauly, D. 1987. A Review of the ELEFAN System for Analysis of Length-Frequency Data in Fish and Aquatic Invertebrates. In Length-Based Methods in Fisheries Research. ICLARM Conference Proceedings 13, 468pp. D. Pauly and G.R. Morgan (eds). International Center for Living Aquatic Resources Management, Manila, Philippines, and Kuwait Institute for Scientific Research, Safat, Kuwait: $7-34 p$.

Pinheiro, A. P. \& J. E. Lins-Oliveira. 2006. Reproductive biology of Panulirus echinatus (Crustacea: Palinuridae) from São Pedro and São Paulo Archipelago, Brazil. Nauplius. 14(2): 89-97.

Research Institute for Marine Fisheries. 2012. Report on research of stock assessment and management of penaeid shrimp and blue swimming crabs in the Fisheries Management Area 712 (Java Sea) and 716 (Sulawesi Sea). Jakarta. 132 p. (in Indonesian).
Saputra, S.W. 2005. Population dynamics of fine shrimp (Metapenaeus elegans De Mann 1907) and Its management on Segara Anakan Lagoon, Cilacap, Central Java. Dissertation. Post Graduate School : Bogor Agricultural Institute. 235 p. (in Indonesian).

Saputra, S.W., \& Subiyanto. 2007. Population dynamics of banana shrimp (Penaeus merguiensis De Mann 1907) on the Segara Anakan Lagoon Cilacap, Central Java. Marine Sciences. Vol 12 (3) :157-166. (in Indonesian).

Sparre, P. \& Venema, S. 1999. Introduction to Tropical Fish Stock Assesment. (IntroduksiPengkajian Stok Ikan Tropis, translate: Fisheries Research and Development Center. Book 1: Manual. Fisheries Research and Development Agency. Jakarta.438 p.

Sudjastani, T. 1974. Population dynamics of Indian mackarel fish in the Java Sea. Marine Fisheries Research Report 1 : 30-64. (in Indonesian).

Suman, A. \& D. Nugroho, 1988. Banana shrimp (Penaeus merguiensis de Man) fisheries in the Pemalang and adjacent waters. Journal of Marine Fisheries Research 47 : 13-20. (in Indonesian).

Suman, A., D. Nugroho, \& M. Rijal. 1991. Some biological aspects of banana shrimp (Penaeus merguiensis) in Kupang and Belu waters, East Nusa Tenggara. Journal of Marine Fisheries Research 61: 91-97. (in Indonesian).

Suman, A. 1992. Population dynamics of endeavour shrimp (Metapenaeus ensis de Haan) in the southern inshore of Java. Proceeding of the First Seminar on Marine and Coastal Ecology: 64-71 (in Indonesian).

Suman, A. \& W. Subani, 1994. The study of some biological aspects of banana shrimp (Penaeus merguiensis de Man) in the Demak waters, Center Java. Jorrnal of Marine Fisheries Research $91: 92$ - 104. (in Indonesian).

Suman, A. 1996. The study of some biological aspects of banana shrimp (Penaeus orientalis) in the Cilacap waters Central Java. Dinper XI (33) : 35 41. (in Indonesian).

Suman, A. \& M. Boer. 2005. Size at first maturity, spawning season and growth parameters of endeavour shrimp (Metapenaeus ensis de Hann) in Cilacap and adjacent waters. Journal of 
Indonesian Fisheries Research 11 (2) : 65-71. (in Indonesian).

Suman, A \& C. Umar. 2010. Population dynamic of banana shrimp (Penaeus merguiensis de Mann) in the Kotabaru waters, South Borneo. Journal of Indonesian Fisheries Research. 1: 29-33 (in Indonesian).

Sumiono, B. 1983. Size on maturity and the sex ration of banana shrimp (Penaeus merguiensis de Man) in the Bintuni Bay, Irian Jaya. Marine Fisheries Research Report 29: 41-46. (in Indonesian).

Sumiono, B \& A.Djamali, 2006. Exploitation of shrimp and demersal fish in the border waters Nunukan -
Tawau, East Borneo. Proceeding of the Fisheries Result on the Sapa Segajah Coral Reef Ecosystem and East Borneo Estuary Ecosystem. Faculty of Marine and Fisheries Mulawarman University Regional Planning and Development Easr Borneo - RCCP,MMAF - Research Center for Oceanography LIPI: 130-147 (in Indonesia).

Udupa, K.S., 1986. Statistical method of estimating the size of first maturity in fish. Fishbyte 4(2) : 811.

Wedjatmiko \& Yulianti. 2003. Some biological aspects of banana shrimp (Penaeus merguiensis) in the Mayangan waters, northern inshore of West Java. Journal of Indonesian Fisheries Research 9(3): 2734. (in Indonesia). 